\title{
Stability and mechanical evaluation of bovine pericardium cross-linked with polyurethane prepolymer in aqueous medium
}

\author{
Birzabith Mendoza-Novelo ${ }^{a}$, Diego I. Alvarado-Castro ${ }^{\mathrm{b}}$, José L. Mata-Mata ${ }^{\mathrm{b}, *}$, Juan V. Cauich-Rodríguez ${ }^{\mathrm{c}}$, \\ Arturo Vega-González a , Eduardo Jorge-Herrero ${ }^{d}$, Francisco J. Rojo ${ }^{\mathrm{e}}$, Gustavo V. Guinea ${ }^{\mathrm{e}}$
}

\begin{abstract}
A B S T R A C T
The present study investigates the potential use of non-catalyzed water-soluble blocked polyurethane prepolymer (PUP) as a bifunctional cross-linker for collagenous scaffolds. The effect of concentration (5, 10, 15 and 20\%), time $(4,6,12$ and $24 \mathrm{~h})$, medium volume $(50,100,200$ and $300 \%)$ and $\mathrm{pH}(7.4,8.2,9$ and 10$)$ over stability, microstructure and tensile mechanical behavior of acellular pericardial matrix was studied. The cross-linking index increased up to $81 \%$ while the denaturation temperature increased up to $12{ }^{\circ} \mathrm{C}$ after PUP crosslinking. PUP-treated scaffold resisted the collagenase degradation $(0.167 \pm 0.14 \mathrm{mmol} / \mathrm{g}$ of liberated amine groups vs. $598 \pm 60 \mathrm{mmol} / \mathrm{g}$ for non-cross-linked matrix). The collagen fiber network was coated with PUP while viscoelastic properties were altered after cross-linking. The treatment of the pericardial scaffold with PUP allows (i) different densities of cross-linking depending of the process parameters and (ii) tensile properties similar to glutaraldehyde method.
\end{abstract}

\section{Introduction}

The use of natural tissues for manufacturing tissue engineering scaffolds has been increased in the last years [1]. Among them, bovine pericardium is widely employed in the construction of heart valves [2-4], vascular grafts $[5,6]$ and patches for abdominal or vaginal wall repair $[7,8]$. Pericardial tissue contains mainly type I collagen hierarchically arranged at different levels of organization with structures such as fibrils, fibers, fiber bundles and laminates [9]. The network of collagen fibers is embedded in an amorphous matrix [10-12]. Therefore, the pericardial tissue can be considered as a pliable multilaminate composite, which shows nonlinear and anisotropic mechanical behavior [13].

The use of tissue-derived biomaterials requires a pretreatment aimed to reduce the degradation, reduce the immunogenicity and sterilize the tissue $[2,14]$. Several cross-linking methods have been used in order to obtain the ideal procedure to stabilize the collagenbased structure while keeping its mechanical properties. Some of the agents that have been used include glutaraldehyde (GA), genipin [15], triglycidylamine [16], carbodiimide (EDC) [17,18], epoxy compound [19], proanthocyanidin [20], as well as enzymatic [21] or photochemical approaches [22]. Other successful methods for tissue- stabilization make use of macromolecules such as polyacrylamide hydrogel [23], Jeffamines ${ }^{\mathrm{TM}}$ [17] epoxy-terminated polyether [24] and chitosan [25]. The cross-linking process enhances the stability of the collagen matrices, but this treatment should not interfere with cellular ingrowth and angiogenesis [15,26,27]. Thus a precise control of the cross-linking density will provide a method for regulating the structure-property relationships in biological scaffolds [14].

On the other hand, polyurethanes are versatile materials in which the mechanical and biological properties can be tuned depending on the structure of their monomers, i.e., diisocyanates and macrodiols. Hexamethylene diisocyanate [28-31] and polyurethane oligomers [32] have been used as cross-linking agents for biomaterials of biological origin. Despite the low degradation associated to macrophages [29] and low toxicity over fibroblasts [30], the use of diisocyanate as collagen cross-linker has drawbacks related to collagen denaturation by the use of organic solvent [31] and diffusion problems of the cross-linker into the matrix [32]. Bearing this in mind, blocked polyurethane prepolymers (PUP) may offer an advantage due to the high water solubility and reduced risk of manipulation.

The reaction between diisocyanates and hydroxyl-ended poly(ethylene oxide) has been explored in order to yield PUP or macrodiisocyanates. This isocyanate-terminated prepolymer can react with bisulphite salts as proposed by Petersen [33] and explored by Guise et al. [34,35] to obtain water-soluble PUP with carbamoylsulfonate-protected isocyanate groups. If protected groups are deblocked in aqueous medium, isocyanate groups are generated and the resulting PUP could be used for cross-linking of 
collagen molecules. These reactions have been used for the re-tanning of leather [36].

Therefore, the purpose of this study was to investigate the capacity to stabilize a bovine pericardium scaffold through their interaction in aqueous media with PUP. Furthermore, the properties of the cross-linked matrix were studied depending on reaction conditions such as concentration, time, volume and pH. For comparison purposes, non-cross-linked acellular tissue and one cross-linked with GA or EDC were used as controls. The indicators of stability for PUPtreated scaffold were the shrinkage temperature, the amine content and the resistance to collagenase degradation. As the crosslinking process can alter the tissue structural features, the effect of PUP cross-linking on mechanical properties was established during the course of this work.

\section{Materials and methods}

\subsection{Materials}

\subsubsection{Tissue preparation}

Bovine pericardium was obtained from a local slaughterhouse immediately after slaughter, rinsed with distilled water to remove blood and body fluids and dissected to remove the external fat. Five $50 \times 40 \mathrm{~mm}$ sections and twelve $15 \times 30 \mathrm{~mm}$ orthogonal sections were cut on the heart ventral surface of two pericardial sacs for the stability and mechanical evaluations, respectively. From twelve sections, six specimens corresponded to the root-to-apex direction (reference, labeled as $0^{\circ}$ ) and six were perpendicular to them (labeled as $90^{\circ}$ or transversal). From each $15 \times 30 \mathrm{~mm}$ sample, three strips of $5 \times 30 \mathrm{~mm}$ were obtained, which were marked with small cuts on the ends to identify the direction and, in turn, randomly divided into three groups.

\subsubsection{Chemicals}

The cross-linker based on carbamoylsulfonate-ended polyurethane prepolymer (PUP) was synthesized according to the method previously described by Mata-Mata et al. [36]. The PUP used in this study is based on the macrodiol poly(ethylene oxide) of $1000 \mathrm{Da}$ (SigmaAldrich) and hexamethylene diisocyanate (HDI Aliphatic isocyanates Luxanate HM, Lyondell). Poly(ethylene glycol) was used in the procedure as it is known to increases the surface hydrophilicity in many synthetic biomaterials [37] and because it improves the hemo-compatibility and calcification resistance in cross-linked tissue [38,39].

Glutaraldehyde (GA), magnesium oxide, disodium piperazine-1,4diethanesulphonate hydrate (PIPES), 1-(3-dimethyl amino propyl)-3ethyl carbodiimide hydrochloride (EDC) and collagenase type I were purchased from SigmaAldrich while ninhydrin from Merck.

\subsection{Methods}

\subsubsection{Tissue decellularization}

Pericardial tissue was decellularized according to the protocol based on the non-ionic detergent tridecyl alcohol ethoxylate. This decellularization method preserves the collagen structural network, anisotropy, tensile modulus, tensile strength and maximum strain at failure of native pericardial matrix [40].

\subsubsection{Tissue cross-linking procedure with PUP}

Cross-linking reaction was carried out by PUP addition to hydrated decellularized tissue in saline buffer solutions (SBS, $0.9 \% \mathrm{NaCl}, 0.03 \mathrm{M}$ PIPES pH 7.4) under orbital agitation ( $30 \mathrm{rpm}$ ) for $3 \mathrm{~h}$ at $24^{\circ} \mathrm{C}$. After this conditioning step, the $\mathrm{pH}$ of the solution dropped from 7.4 to 6.6. In a second reaction step, magnesium oxide (MgO) was added to increase the $\mathrm{pH}$ and the cross-linking reaction was at different times. The cross-linking was halted by removing PUP-treated tissues from the solution and washing them thoroughly with distilled water and SBS containing $0.03 \mathrm{M}$ EDTA. Finally, cross-linked samples were stored at $4{ }^{\circ} \mathrm{C}$ in SBS until the physicochemical and mechanical evaluations were carried out.

The variables studied for the cross-linking reaction were PUP concentration, reaction time, $\mathrm{pH}$ and reaction medium volume.

PUP concentrations: $5,10,15$ or $25 \% \mathrm{v} / \mathrm{v}$ of PUP was added to tissue/SBS $(1: 1, \mathrm{~g}: \mathrm{ml})$ keeping the $\mathrm{pH} 8.2$ during $12 \mathrm{~h}$.

Cross-linking time: $15 \% \mathrm{v} / \mathrm{v}$ of PUP was added to tissue/SBS (1:1, $\mathrm{g}: \mathrm{ml})$, the $\mathrm{pH}$ adjusted to 8.2 and the cross-linking reaction followed during $4,6,12$ or $24 \mathrm{~h}$.

Cross-linking $\mathrm{pH}: 0.05,0.2,0.5$ or $1 \% \mathrm{v} / \mathrm{v}$ of $\mathrm{MgO}$ was added to increase the $\mathrm{pH}$ in the second reaction step until close to the values 7.4, $8.2,9$ and 10. Reaction was conducted with a relationship $1: 1$ (g:ml) of tissue/SBS, $15 \% \mathrm{v} / \mathrm{v}$ of PUP and stopped at $12 \mathrm{~h}$.

Reaction volume: Ratios 1:0.5, 1:1, 1:2 and 1:3 (g:ml) of tissue/SBS were used. Cross-linking was conducted with $15 \%$ v/v of PUP, at pH 8.2 and stopped at $12 \mathrm{~h}$.

Acellular bovine pericardium cross-linked with GA $(0.625 \%, 24 \mathrm{~h}$, pH 7.4, $\left.24{ }^{\circ} \mathrm{C}\right)$ or $\operatorname{EDC}\left(0.1 \mathrm{M}, 24 \mathrm{~h}, \mathrm{pH} 7.4,24{ }^{\circ} \mathrm{C}\right)$ [41] was used as control. The samples were then characterized as follows.

\subsubsection{Thermal stability tests}

The denaturation $\left(T_{d}\right)$ or shrinkage $\left(T_{s}\right)$ temperature was determined in all modified samples by either differential scanning calorimetry (DSC 7, Pyrus1, Perkin-Elmer) or standard method ASTM D-6076-97 [42]. When DSC was used, hydrated samples (5-9 mg) were placed in aluminum pans for liquids and then sealed hermetically. The experiments were performed in triplicate from 40 to $140{ }^{\circ} \mathrm{C}$ at a heating rate of $10^{\circ} \mathrm{C} / \mathrm{min}$. $\mathrm{T}_{\mathrm{d}}$ is reported as the temperature at the peak of the endothermic transition during the first DSC trace. Enthalpy $(\Delta H)$, height and half-width of the denaturation peaks were calculated after a baseline was drawn. In the second method, hydrated tissue strips $(5 \times 20 \mathrm{~mm})$ were placed between two clamps (one static and one mobile) of an Otto Spechs equipment (70435, Stuttgart, Germany) and heated in distillated water from 40 to $90{ }^{\circ} \mathrm{C}$ at $3{ }^{\circ} \mathrm{C} / \mathrm{min}$. $\mathrm{T}_{S}$ is recorded as the water temperature in which the onset of tissue shrinkage is detected.

\subsubsection{Cross-linking index test}

Density of the cross-linking was determined by changes in concentration of residual amines $\left[\mathrm{NH}_{2}\right]$ by means of ninhydrin assay [41]. Hydrated samples were placed in contact with an aqueous citrate $(\mathrm{pH} 5.0)$ solution containing $1.0 \% \mathrm{w} / \mathrm{v}$ of ninhydrin and then heated at $95{ }^{\circ} \mathrm{C}$ for $20 \mathrm{~min}$. Finally, the solutions were cooled to $25^{\circ} \mathrm{C}$ and their optic densities were measured at $567 \mathrm{~nm}$ (UV-vis spectrophotometer, Beckman Coulter DU 650). After this, samples were lyophilized and weighted. $\left[\mathrm{NH}_{2}\right]$ ( $\mathrm{mmol} / \mathrm{g}$ of dry tissue) was calculated using the molar absorptivity $(\varepsilon)$ for the blue-violet dye (Ruhemann's purple) of $1640 \mathrm{ml} / \mathrm{mol} \cdot \mathrm{cm}$. The cross-linking index was expressed as the percentage change in $\left[\mathrm{NH}_{2}\right]$ of non-cross-linked tissue after cross-linking.

\subsubsection{Resistance towards collagenase digestion}

Resistance to enzymatic degradation of the cross-linked matrix was determined by the weight loss and the amines released when tissue was incubated in a solution containing collagenase. For these experiments, hydrated tissue samples $(\sim 100 \mathrm{mg})$ were incubated in $1 \mathrm{ml}$ of $0.05 \mathrm{M}$ Tris $\cdot \mathrm{HCl}$ solution (pH 7.4) containing $0.03 \% \mathrm{w} / \mathrm{v} \mathrm{NaN}_{3}$, $0.25 \mathrm{mg} / \mathrm{ml}$ collagenase type I ( $288 \mathrm{U} / \mathrm{mg}$ solid) of Clostridum histolyticum and $0.005 \mathrm{M} \mathrm{CaCl}_{2} \cdot 2 \mathrm{H}_{2} \mathrm{O}$ for $20 \mathrm{~h}$ at $37^{\circ} \mathrm{C}$. Then, samples were removed from collagenase solution, washed with Tris $\cdot \mathrm{HCl}$ buffered solution containing $0.03 \% \mathrm{NaN}_{3}$ and $0.005 \mathrm{M}$ EDTA, lyophilized and weighted. The weight loss was obtained using the wet/dry ratio of degraded and non-degraded samples. The amines released from tissue were determined in the supernatant using the ninhydrin assay described previously. $100 \mu$ of the supernatant with and without (as blank) digestion of non-cross-linked and cross-linked tissue was used. 


\subsubsection{Swelling}

Thickness of pericardial matrix was determined prior and after cross-linking with GA or PUP ( $15 \% \mathrm{v} / \mathrm{v}, \mathrm{pH} 9,12 \mathrm{~h}$ ) using a Mitutoyo Elecount micrometer. In another experimental set, the masses of non-cross-linked and cross-linked tissue stored in saline solution were determined prior and after drying at $60^{\circ} \mathrm{C}$ for $20 \mathrm{~h}$. The swelling was expressed as the percentage of change in thickness and in water content of pericardial tissue after cross-linking.

\subsubsection{Tensile mechanical properties}

The mechanical evaluations were carried out with non-cross-linked-, GA-cross-linked- and (15\%, pH 9, 12 h) PUP-cross-linked-tissue strips. The mean thickness of each strip was determined by series of measurements at four different points using a Mitutoyo Elecount micrometer. Specimens with an effective gauge length of $20 \mathrm{~mm}$ were placed in an electromechanical tensile testing machine (Instron 4411) adapted with a transparent chamber and immersed in a saline solution heated at $37{ }^{\circ} \mathrm{C}$ by a thermostatic bath (Unitronic 6320200) [43]. Then, stress relaxation tests were performed by stretching first the tissue strip to a given stress of $200 \mathrm{kPa}$ using a crosshead speed of $50 \mathrm{~mm} / \mathrm{min}$; the movable crosshead was then stopped and the load from the tissue recorded over $100 \mathrm{~s}$. After this, the stress relaxation tests were repeated using $1000 \mathrm{kPa}$ as the initial stress. Finally, tissue strips were unloaded and then re-stretched to rupture at an extension rate of $1.8 \mathrm{~mm} / \mathrm{min}$.

The axial force was measured with the tensile testing machine by means of a $100 \mathrm{~N}$ load cell (Instron 2519-101) and the elongation by the internal LVDT sensor. The crosshead displacement was taken as a direct measurement of the sample elongation, since the compliance of the sample had been estimated as 100 times that of the equipment. Prior and after each stress relaxation test, few load cycles between 0 and $0.1 \mathrm{~N}$ were applied to every sample until a reproducible response with a negligible hysteresis loop was achieved.

\subsubsection{Mechanical properties analysis}

For stress relaxation tests, the ratio of stress at a time $t, o(t)$, to the initial stress $\left(\sigma_{0}\right)$ was plotted versus time on a logarithmic scale. These curves were fitted by linear regression in two zones [44]; an initial relaxation slope between 0 and $1 \mathrm{~s}$ and $\mathrm{a}$ final relaxation slope between 1 and $100 \mathrm{~s}$. The stress relaxation ratio at $100 \mathrm{~s}$ was calculated as the ratio of $\mathrm{o}_{\mathrm{o}}$ to $\sigma(100 \mathrm{~s})$.

Stress-strain relationships for all the tests were derived from loaddisplacement curves. Strain was obtained by dividing the increment of specimen length by initial length, and stress was calculated as the applied load divided by the initial cross-sectional area (width $\times$ thickness). The tissue elastic modulus was assessed from the slope at the linear stiff region, displayed at high stresses. The pericardium specimen rupture was characterized by the stress and strain at the point when the first layer of the tissue failed, identified by a sudden drop of the load. The tangent modulus, calculated as the first derivative of the stress-strain curve, was obtained for the initial region (between 0 and $0.6 \mathrm{MPa}$ ) of the stress-strain curves, and fit to a straight line [10] to compute its initial slope.

\subsubsection{SEM analysis}

The morphology and structural integrity of acellular and $(15 \% \mathrm{v} / \mathrm{v}$, $\mathrm{pH} 9,12 \mathrm{~h}$ ) PUP cross-linked tissue samples was observed by low-vacuum scanning electron microscopy (SEM, JEOL, JSM 6360LV). For this, wet samples were frozen with liquid nitrogen and then examined by SEM.

\subsubsection{In vitro mineralization test}

The mineralization within tissue cross-linked with PUP (15\%, SBS/ tissue $1: 1 \mathrm{ml}: \mathrm{g}, \mathrm{pH} 8.2,12 \mathrm{~h}$ ) was performed using simulated body fluid (Kokubo's SBF) [25]. Samples were soaked in SBF for 14 days at $37^{\circ} \mathrm{C}$ under orbital agitation $(30 \mathrm{rpm})$. The solution was replaced every two days by fresh SBF. In order to determine the calcium and phosphorus accumulation in samples, specimens were rinsed in water, vacuum dried and weighed. The dry samples were hydrolyzed in $6 \mathrm{~N} \mathrm{HCl}$ at $100{ }^{\circ} \mathrm{C}$ for $24 \mathrm{~h}$ and calcium content was quantified by atomic absorption spectrometry, and phosphorus by a molybdate reagent solution (Fluka analytical) [45]. Calcium and phosphorus levels are expressed as $\mathrm{mg} / \mathrm{g}$ dry weight tissue.

\subsubsection{Statistical analysis}

The statistical analysis was performed with one-way analysis of variances (ANOVA). The Sidak-Holm Test was used for the comparison between data groups. The results were considered significantly at $p$ values less than 0.05 and presented as mean \pm standard deviation (SD).

\section{Results}

\subsection{PUP processed pericardial tissue stability}

\subsubsection{Effect of the processing time and concentration}

PUP treated tissue showed different levels of stability, as both the shrinkage temperature $\left(\mathrm{T}_{\mathrm{S}}\right)$ and the cross-linking index $(\mathrm{CI})$ depended on the cross-linking time and the PUP concentration. The $\mathrm{T}_{\mathrm{s}}$ increased until $12 \mathrm{~h}$ of reaction ( $\mathrm{pH} \mathrm{8.2,15 \%} \mathrm{PUP)} \mathrm{but} \mathrm{no} \mathrm{statistical} \mathrm{change} \mathrm{was} \mathrm{ob-}$ served thereafter (Table 1). Moreover, no significant changes were observed in $\mathrm{T}_{\mathrm{s}}$ when the reaction $(\mathrm{pH} 8.2,12 \mathrm{~h}$ ) proceeds with 15 or $25 \%$ of PUP (Table 1). The $T_{s}$ of the control materials, i.e., non-cross-linked tissue and GA-treated tissue was $66.7 \pm 1.2{ }^{\circ} \mathrm{C}$ and $81.5 \pm 1.2{ }^{\circ} \mathrm{C}$, respectively. The $\mathrm{CI}$ reached a constant value of $53.7 \%$ after $6 \mathrm{~h}$ of reaction (pH 8.2, 15\% PUP), but it increased up to $70 \%$ with a PUP concentration of $25 \%$ ( $\mathrm{pH} 8.2,12 \mathrm{~h})$.

\subsubsection{Effect of the processing $p H$}

Both the $\mathrm{T}_{\mathrm{S}}$ and the $\mathrm{CI}$ increased with $\mathrm{pH}$ in the second step of the cross-linking process (Fig. 1). The highest $\mathrm{CI}$ achieved in PUP-treated material was $82 \%$, whereas the GA-treated tissue reached one of $89.7 \pm 1.5 \%$. The $\mathrm{T}_{\mathrm{S}}$ increased $13{ }^{\circ} \mathrm{C}$ when decellularized tissue was treated with PUP at pH 10 (Fig. 1a). The resistance towards collagenase digestion was evaluated as the concentration of soluble fragments of collagen released to solution after cleaving peptide bonds and the retained solid mass. Significant changes in the two parameters used to evaluate the enzymatic resistance were observed (Fig. 1b). The amount of amine released from non-cross-linked matrix to the supernatant was lower in tissue treated with PUP or GA. GA-treated matrix, as control, liberated only $1.38 \pm 1.0 \mathrm{mmol} / \mathrm{g}$ of amine after degradation. The remaining mass in all stabilized samples was close to $90 \%$, while it was $40 \%$ for non-cross-linked (Fig. 1b).

\section{Table 1}

Effect of cross-linking reaction time and PUP concentration on the shrinkage temperature $\left(\mathrm{T}_{\mathrm{s}}\right)$ and cross-linking index $(\mathrm{CI})$ of PUP-treated pericardial matrix.

\begin{tabular}{llllll}
\hline \multicolumn{5}{l}{ Effect of time } & \multicolumn{5}{l}{} \\
\hline Time $(\mathrm{h})$ & 0 & 4 & 6 & 12 & 24 \\
\hline $\mathrm{T}_{\mathrm{s}}\left({ }^{\circ} \mathrm{C}\right)$ & $66.7 \pm 1.2$ & $70.1 \pm 1.1^{\mathrm{a}}$ & $72.1 \pm 1.0^{\mathrm{a}, \mathrm{b}}$ & $73.9 \pm 1.1^{\mathrm{a}, \mathrm{b}}$ & $74.4 \pm 1.1^{\mathrm{a}, \mathrm{b}}$ \\
$\mathrm{CI}(\%)$ & - & $39.5 \pm 8.0$ & $53.7 \pm 7.3^{\mathrm{b}}$ & $53.6 \pm 11.1^{\mathrm{b}}$ & $58.3 \pm 11.6^{\mathrm{b}}$ \\
& & & & \\
Effect of concentration & & & & \\
\hline PUP concentration $(\%)$ & 5 & 10 & 15 & 25 \\
$\mathrm{~T}_{\mathrm{S}}\left({ }^{\circ} \mathrm{C}\right)$ & $70.5 \pm 1.0$ & $73.1 \pm 0.8^{\mathrm{c}}$ & $73.9 \pm 1.1^{\mathrm{c}}$ & $74.2 \pm 0.9^{\mathrm{c}}$ \\
$\mathrm{CI}(\%)$ & $45.9 \pm 9.0$ & $51.9 \pm 8.6$ & $53.6 \pm 11.1$ & $70.0 \pm 6.0^{\mathrm{c}}$ \\
\hline
\end{tabular}

$\mathrm{n}=5 ;$ mean $\pm \mathrm{SD}$.

${ }^{\mathrm{a}} \mathrm{p}<0.002$ vs. $0 \mathrm{~h}$

b $\mathrm{p}<0.049$ vs. $4 \mathrm{~h}$

c $\mathrm{p}<0.002$ vs. $5 \%$. 


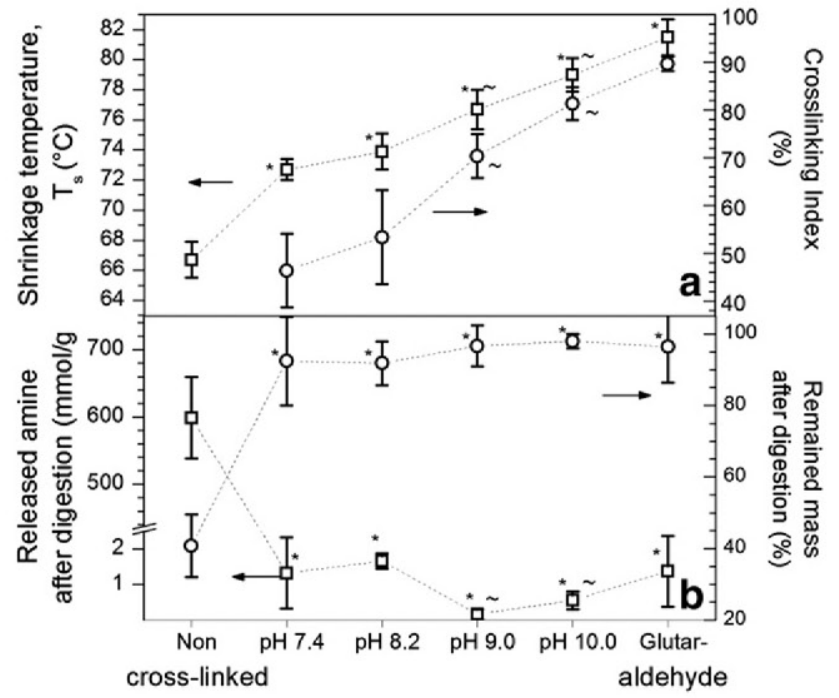

Fig. 1. Effect of cross-linking $\mathrm{pH}$ on a) the shrinkage temperature (measured by ASTM D-6076-97) and cross-linking index, and b) the released amine groups and remaining mass after collagenase digestion of PUP-treated tissue. Data are expressed as mean values $\pm S D, n=5,{ }^{*} p<0.001$ vs. non-cross-linked, $p<0.01$ vs. $\mathrm{pH} 7.4$.

\subsubsection{Effect of the processing volume}

Both the $\mathrm{T}_{\mathrm{S}}$ and the $\mathrm{Cl}$ showed lower values with higher reaction volume in PUP-treated matrix (Fig. 2a). Nonetheless, the enzymatic degradation resistance for PUP-treated tissue was independent of the cross-linking degrees (Fig. 2b). The DSC results confirmed the participation of PUP in the collagen cross-linking and validated the relationship between reaction volume and the stability differences (Table 2). DSC profiles of PUP-treated matrix revealed an increase of $12{ }^{\circ} \mathrm{C}$ in $\mathrm{T}_{\mathrm{d}}$ of non-cross-linked matrix. The denaturation peak's width at half-height in the PUP-treated pericardium was higher than in the control tissue (decellularized, GA, EDC), on the other hand, samples treated with PUP at a lower dilution factor showed a higher half-width (Table 2).

\subsection{Swelling and micro structural characteristics}

A stabilization-related adverse phenomenon is the drop in tissue hydration after cross-linking. Dehydration induced by GA or EDC treatment

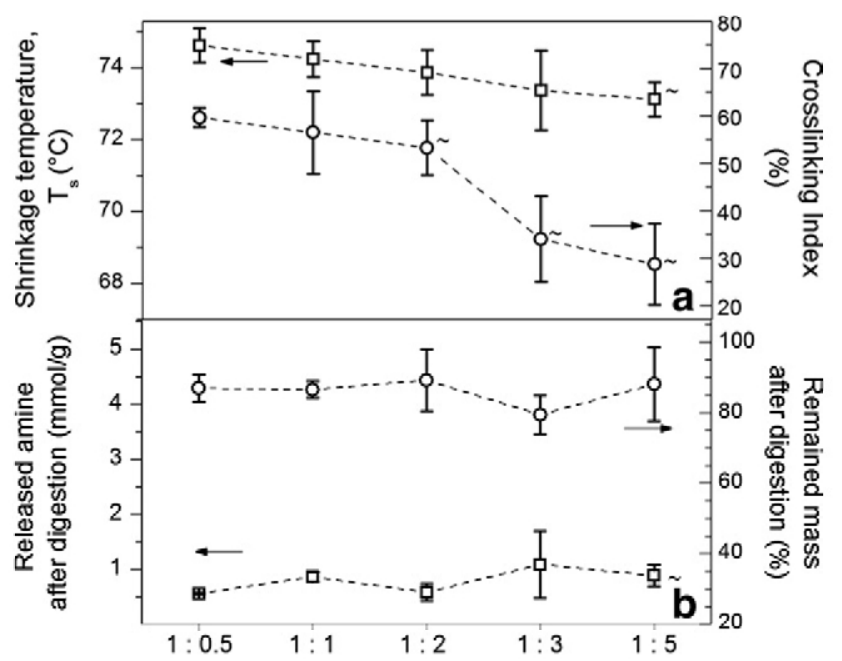

Fig. 2. Effect of cross-linking medium volume on a) the shrinkage temperature (measured by ASTM D-6076-97) and cross-linking index, and b) the released amine groups and remaining mass after collagenase digestion of PUP-treated tissue. Data are expressed as mean values $\pm S D, n=5,^{\sim} \mathrm{p}<0.047$ vs. $1: 0.5$.
Table 2

DSC results (denaturation temperature at peak $\left(T_{d}\right)$, the height, the width at half height and the enthalpy of the denaturation peaks) for non-cross-linked and glutaraldehydeEDC- or PUP-cross-linked matrix.

\begin{tabular}{|c|c|c|c|c|}
\hline Material & $\mathrm{T}_{\mathrm{d}}\left({ }^{\circ} \mathrm{C}\right)$ & Height (mW) & Half-width $\left({ }^{\circ} \mathrm{C}\right)$ & $\Delta \mathrm{H}(\mathrm{J} / \mathrm{g})$ \\
\hline Non-cross-linked & 70.1 & 1.24 & 2.94 & 4.16 \\
\hline Glutaraldehyde & 84.3 & 1.75 & 1.74 & 5.50 \\
\hline EDC & $74.6 \pm 0.5$ & 1.63 & 2.16 & 5.59 \\
\hline PUP $-1: 0.5^{\mathrm{a}}$ & 82.0 & 1.23 & 4.29 & 4.26 \\
\hline PUP $-1: 1^{a}$ & 81.1 & 1.38 & 3.66 & 5.24 \\
\hline$P U P-1: 2^{a}$ & 80.5 & 1.54 & 3.12 & 4.19 \\
\hline PUP $-1: 3^{a}$ & 79.6 & 0.94 & 3.11 & 4.58 \\
\hline
\end{tabular}

$\mathrm{n}=3$; mean $\pm \mathrm{SD},{ }^{\mathrm{a}} 15 \% \mathrm{v} / \mathrm{v}, \mathrm{pH} 9,12 \mathrm{~h}$, relationships tissue mass:volume (g:ml).

was more severe than in PUP-treated samples (Table 3). In addition, the mean thickness of the stabilized pericardial tissue samples was higher and statistically different than non-cross-linked tissue mean thickness. In spite of these differences, PUP-treated tissue retained the collagen network of non-cross-linked tissue (Fig. 3). Collagen fibers, randomly orientated and stacked in layers, in acellular pericardium were also coated with PUP after cross-linking as observed by SEM on the tissue fibrosa surface (Fig. 3).

\subsection{Mineralization in $S B F$}

After 14 days' incubation in SBF, PUP-treated tissue showed similar calcium and phosphorus content compared to acellular non-crosslinked tissue (Fig. 4). The highest calcium and phosphorus content corresponded to GA-treated pericardium. However, levels of calcium and phosphorus showed a wide variation in tissue samples treated with GA.

\subsection{Mechanical properties of processed pericardial tissue}

\subsubsection{Stress relaxation properties}

The stress relaxation was used to compare the viscoelastic properties of acellular and cross-linked pericardial tissue (Fig. 5). Stress relaxation at $100 \mathrm{~s}$ was reduced after cross-linking of pericardial tissue with GA or PUP for both strip directions (Table 4). Moreover, this difference was observed at both initial stress levels of $200 \mathrm{kPa}$ and $1000 \mathrm{kPa}$ (Table 4).

\subsubsection{Stress-strain response}

The stress-strain response of acellular tissue is dependent on the strips' direction, however, this dependence disappeared after matrix cross-linking (Fig. 6a). For non-cross-linked tissue, the transition point between the compliant portion of the stress-strain curves and the stiffer one occurred at higher strains in the transversal direction than in the root-to-apex strips (Fig. 6b). The modification of the stress-strain response after crosslinking is highlighted with the tangent modulus vs. stress curves [10], as shown in Fig. 7, that along with the elastic modulus

Table 3

Swelling parameters for non-cross-linked and PUP- $(15 \% \mathrm{v} / \mathrm{v}, \mathrm{pH} 9,12 \mathrm{~h})$ or glutaraldehyde- cross-linked pericardial matrix.

\begin{tabular}{lll}
\hline & Water content (\%) & Thickness (mm) \\
\hline Non-cross-linked & $79.5 \pm 1.3$ & $0.256 \pm 0.030$ \\
PUP & $74.1 \pm 2.0^{\mathrm{a}}$ & $0.295 \pm 0.046^{\mathrm{a}}$ \\
Glutaraldehyde & $64.8 \pm 2.0^{\mathrm{a}, \mathrm{b}}$ & $0.329 \pm 0.041^{\mathrm{a}, \mathrm{b}}$ \\
EDC & $63.5 \pm 1.4$ & $0.359 \pm 0.071$ \\
\hline
\end{tabular}

$\mathrm{n}=6$; mean $\pm S D$

a $\mathrm{p}<0.003$ vs. non-cross-linked.

b $\mathrm{p}<0.006$ vs. PUP. 

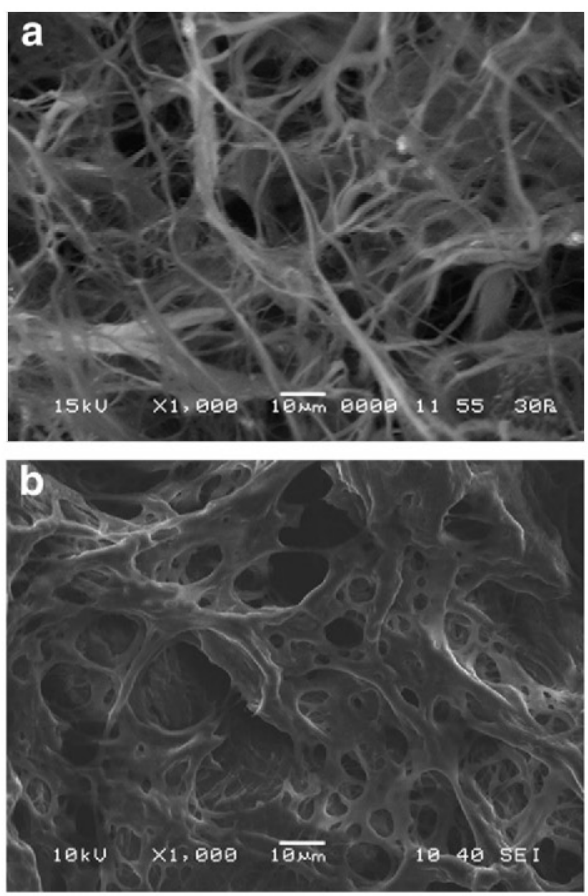

Fig. 3. Representative SEM micrographs for non-cross-linked (a) and (15\%, pH 9, $12 \mathrm{~h}$ ) PUP-treated (b) pericardial matrix in fibrosa surface.

are independent of the orthogonal directions after cross-linking (Table 5).

\subsubsection{Tensile strength and strain at rupture}

The cross-linking of pericardial scaffold with GA or PUP caused a reduction in the tensile strength, but increasing the strain at rupture (Fig. 8). Nonetheless, these mechanical properties were similar in matrix treated with PUP and GA. In acellular pericardial matrix, the rupture parameters were higher for the transversal direction than for root-to-apex direction but this dependence was reduced in cross-linked ones (Fig. 8).

\section{Discussion}

Biological scaffolds for tissue engineering should not only provide mechanical support for cell proliferation but also must be stable to control the degradation rates. It is well know that stabilization of tissue-derived biomaterial is a result of cross-linking reactions between two reactive sites in collagen and bi-functional molecules, i.e., cross-linkers. The cross-linking process as well as its extension impacts the mechanical properties [15,16], biodegradation [14,29] and porosity [46] of collagenous tissues. In this study we propose the potential use of a water-soluble polyurethane prepolymer (PUP) as a bifunctional cross-linker for collagenous scaffolds by studying the effect

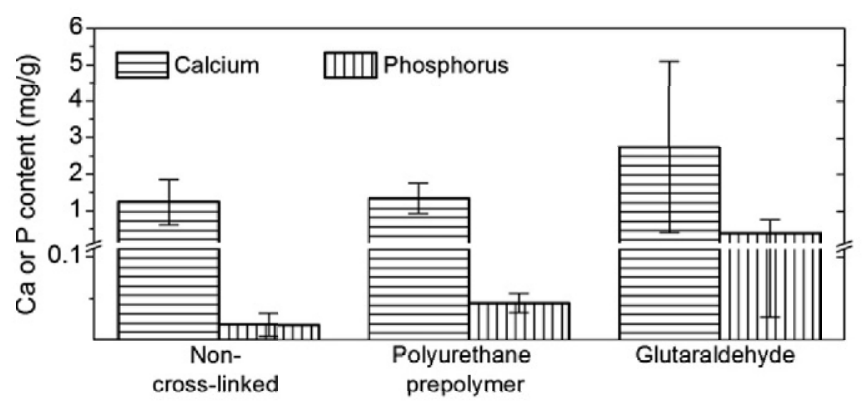

Fig. 4. Content of calcium and phosphorus in non-cross-linked and cross-linked matrix after soaking in SBF. Data are expressed as mean values $\pm S D, n=4$.

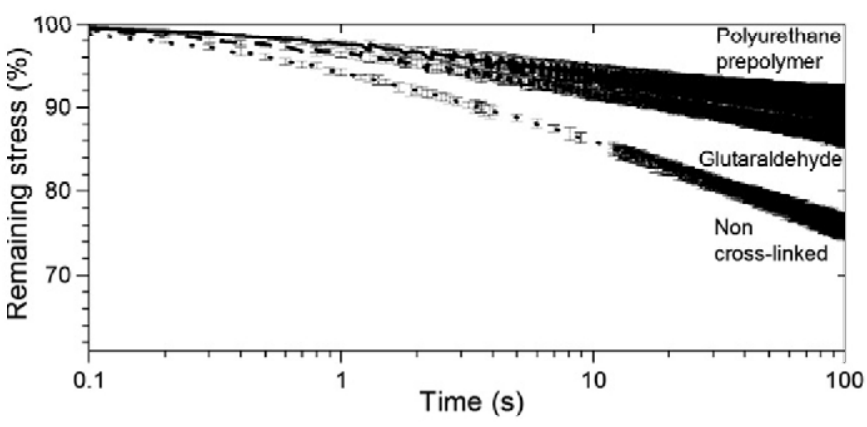

Fig. 5. Stress relaxation curves for non-cross-linked and cross-linked strips in the transversal direction. Data are expressed as mean values $\pm S D, n=6$.

of reaction parameters on the cross-linking density and the tensile properties of acellular pericardial matrix.

\subsection{Effect of cross-linking parameters on stability}

Being that PUP was obtained from poly(ethylene glycol) and that isocyanates were blocked by the formation of carbamoylsulfonate end groups [33-36], the cross-linking process was carried out in aqueous medium. The medium $\mathrm{pH}$ control solves the diffusion problems, as evidenced by the complete coating of the collagen network with PUP (Fig. 3). PUP diffusion into the tissue without or with reduced crosslinking reactions is favored by an initial $\mathrm{pH}$ of 6.6. An increase in collagen stability occurs with an increase of reaction pH (Fig. 1). Isocyanate groups in PUP can potentially react with collagen functional side groups, such as $-\mathrm{NH}_{2},-\mathrm{OH},-\mathrm{COOH}$ or $-\mathrm{NHCO}-$, when reaction conditions are appropriated. Nucleophilic attack by non-protonated amines on slightly electropositive carbonyl carbon of the isocyanate groups occurs at relatively higher rates compared to other functional groups [32]. Formation of cross-linking urea bonds is promoted by the high concentration of both PUP and $-\mathrm{NH}_{2}$ (when $\mathrm{pH}$ is increased), this in turn, is translated as an increase in both the $\mathrm{T}_{\mathrm{S}}$ and the $\mathrm{Cl}$ (Table 1, Fig. 1). In contrast, the increment of the medium volume produces a diminution of $\mathrm{T}_{\mathrm{S}}$ and $\mathrm{CI}$ (Fig. 2). It is possible that high solvent:tissue ratios can induce a diminution in the apparent reactivity of PUP and/or promote secondary reactions between water and isocyanate groups or intra-molecular reactions between PUP molecules. Although the ninhydrin assay provides information regarding free amines, the presence of less free amine is not a precise manner for assessing tissue stability due to masking reactions,

Table 4

Stress relaxation parameters for non-cross-linked (NC) and PUP- (15\% v/v, pH 9, $12 \mathrm{~h})$ or glutaraldehyde- (GA) cross-linked pericardial matrix in both orthogonal directions.

\begin{tabular}{|c|c|c|c|}
\hline & $\begin{array}{l}\text { Initial relaxation slope } \\
\text { (\% Remaining stress vs. } \\
\text { Log(s)) }\end{array}$ & $\begin{array}{l}\text { Final relaxation slope } \\
\text { (\% Remaining stress vs. } \\
\log (s) \text { ) }\end{array}$ & $\begin{array}{l}\text { Stress relaxation } \\
\text { ratio at } 100 \mathrm{~s}\end{array}$ \\
\hline \multicolumn{4}{|c|}{ Initial stress of $200 \mathrm{kPa}$} \\
\hline NC $90^{\circ}$ & $-5.73 \pm 0.59^{\mathrm{a}}$ & $-8.81 \pm 2.29$ & $1.23 \pm 0.10$ \\
\hline $\mathrm{NC} 0^{\circ}$ & $-3.48 \pm 0.87$ & $-7.32 \pm 3.96$ & $1.41 \pm 0.22$ \\
\hline PUP $90^{\circ}$ & $-2.04 \pm 0.97^{b}$ & $-3.88 \pm 0.98^{\mathrm{b}}$ & $1.11 \pm 0.02^{\mathrm{b}}$ \\
\hline PUP $0^{\circ}$ & $-1.27 \pm 0.34^{b}$ & $-3.32 \pm 0.64$ & $1.12 \pm 0.01^{\mathrm{b}}$ \\
\hline GA $90^{\circ}$ & $-1.97 \pm 0.85^{b}$ & $-5.60 \pm 0.43^{b}$ & $1.15 \pm 0.06$ \\
\hline $\mathrm{GA} 0^{\circ}$ & $-1.76 \pm 0.24^{b}$ & $-4.44 \pm 1.34$ & $1.18 \pm 0.01$ \\
\hline \multicolumn{4}{|c|}{ Initial stress of $1000 \mathrm{kPa}$} \\
\hline $\mathrm{NC} 90^{\circ}$ & $-4.28 \pm 0.86$ & $-9.19 \pm 2.56$ & $1.43 \pm 0.13$ \\
\hline $\mathrm{NC} 0^{\circ}$ & $-4.17 \pm 0.67$ & $-9.10 \pm 2.90$ & $1.50 \pm 0.22$ \\
\hline PUP $90^{\circ}$ & $-2.28 \pm 0.88^{b}$ & $-3.80 \pm 1.32^{\mathrm{b}}$ & $1.15 \pm 0.04^{b}$ \\
\hline PUP $0^{\circ}$ & $-2.54 \pm 0.75^{b}$ & $-3.14 \pm 0.57^{b}$ & $1.18 \pm 0.06^{\mathrm{b}}$ \\
\hline $\mathrm{GA} 90^{\circ}$ & $-3.25 \pm 0.46$ & $-6.30 \pm 1.24$ & $1.22 \pm 0.04^{b}$ \\
\hline $\mathrm{GA} 0^{\circ}$ & $-3.06 \pm 0.36^{\mathrm{b}}$ & $-5.68 \pm 1.16$ & $1.25 \pm 0.05^{\mathrm{b}}$ \\
\hline
\end{tabular}

$$
\begin{aligned}
& \mathrm{n}=6 ; \text { mean } \pm S D . \\
& \text { a } p<0.012 \text { vs. } 0^{\circ} . \\
& \text { b } p<0.048 \text { vs. NC. }
\end{aligned}
$$



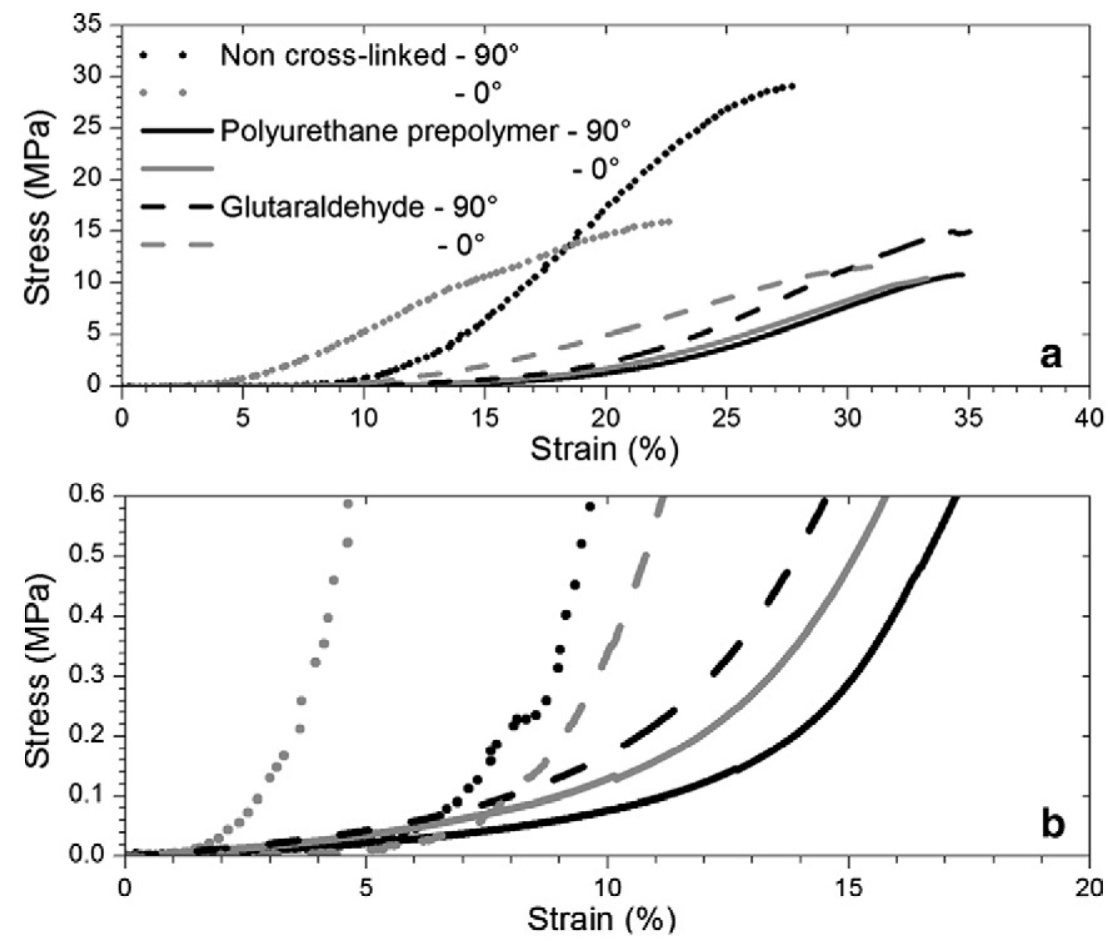

Fig. 6. Representative stress vs. strain curves for non-cross-linked and cross-linked strips in transversal ( $90^{\circ}$, black) and root-to-apex ( $0^{\circ}$, gray) directions, showing a) the complete typical curves and b) a zoom of the initial part.

i.e., reactions on one end only of the bi-functional cross-linker. The relationship between $\mathrm{Cl}$ and temperature of the collagen transition from triple helix to a random coil conformation indicates few masking reactions and, therefore an effective cross-linking. The resistance towards collagenase digestion confirmed the stabilization of tissue with PUP. It is possible that PUP incorporation allowed smaller interstitial spaces impeding enzyme infiltration into tissue and therefore limiting the initial potential degradation to superficial damage. In this regard, Oosthuysen et al. [23] reported a possible mechanism of protection from enzymatic attack by hydrogel filled tissue due to the spatial exclusion of proteases and/or steric interactions. Furthermore, Wei et al. [46] reported a decline of the resistance against collagenase degradation in porous tissues, attributed to more ready penetration of enzymes. In our case, the collagen fiber network is covered with PUP (Fig. 3) which can provide protection to the collagen peptide bonds at all levels of structural organization. PUP can be incorporated into the tissue in different ways according to its molecular weight distribution and the molecular weight of PEG. The stability of PUP-treated tissue was similar to the GA-treated one under certain reaction conditions, however, half-width of the DSC endothermic peak revealed some differences between PUP and GA methods (Table 2). The collagen triple helices cross-linked via a short cross-linker (GA or EDC) behave as molecules more resistant

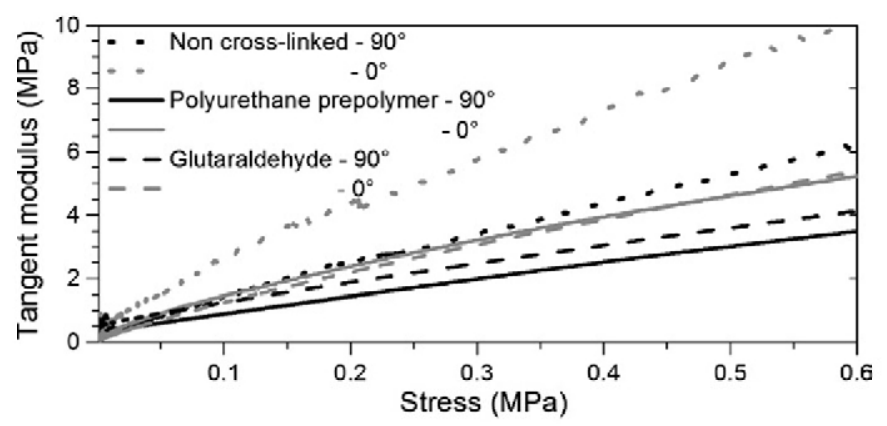

Fig. 7. Representative tangent modulus vs. stress curves for non-cross-linked and cross-linked strips in transversal $\left(90^{\circ}\right.$, black $)$ and root-to-apex $\left(0^{\circ}\right.$, gray $)$ directions. to unfolding than if a long cross-linker is used [17] such as PUP. This can be associated to a lower cooperation of hierarchy structural levels in PUP-cross-linked collagen to respond to the melting of ordained structure than in collagen cross-linked with GA. The influence of the dilution factor on the half-width of the denaturation peak (Table 2 ) is probably related to the number or distribution of the cross-linking sites.

The low level of dehydration in pericardial tissue treated with PUP, unlike that with GA or EDC (Table 3), can be related to the hydrophilic nature of PEG segments in PUP. A more hydrophilic biomaterial can allow a better tissue fluid infiltration and diffusion in addition to in-growth of capillary blood vessels [17] and inhibition of the cell adhesion and spreading [38]. Regarding the preliminary behavior of in vitro mineralization, non-cross-linking and PUP-cross-linking process yielded similar results in calcium and phosphorus accumulation after standard incubation in SBF (Fig. 4).

\subsection{Effect of cross-linking on mechanical properties}

The time-dependent viscoelastic properties of cross-linked and acellular tissue strips were characterized in a physiologically mimicked

Table 5

Stiffness parameters for non-cross-linked (NC) and PUP- (15\% v/v, pH 9, $12 \mathrm{~h})$ or glutaraldehyde- (GA) cross-linked pericardial matrix in both orthogonal directions.

\begin{tabular}{|c|c|c|c|c|}
\hline & \multicolumn{2}{|c|}{$\begin{array}{l}\text { Slope of tangent modulus } \\
\text { (Tangent modulus/stress ratio } \\
\text { (MPa/MPa)) }\end{array}$} & \multicolumn{2}{|c|}{ Elastic modulus (MPa) } \\
\hline & $90^{\circ}$ & $0^{\circ}$ & $90^{\circ}$ & $0^{\circ}$ \\
\hline NC & $13.98 \pm 3.44^{\mathrm{a}}$ & $19.21 \pm 2.5$ & $169.1 \pm 48.1^{a}$ & $102.9 \pm 25.6$ \\
\hline PUP & $4.88 \pm 0.56^{b}$ & $6.41 \pm 1.79^{b}$ & $66.9 \pm 11.4^{\mathrm{b}}$ & $62.3 \pm 20.6$ \\
\hline GA & $6.12 \pm 0.94^{\mathrm{b}}$ & $7.33 \pm 1.86^{\mathrm{b}}$ & $80.4 \pm 20.4^{\mathrm{b}}$ & $69.0 \pm 15.9^{\prime}$ \\
\hline
\end{tabular}

$\mathrm{n}=6$; mean \pm SD

a $\mathrm{p}<0.014$ vs. $0^{\circ}$

b $\mathrm{p}<0.022$ vs. NC. 


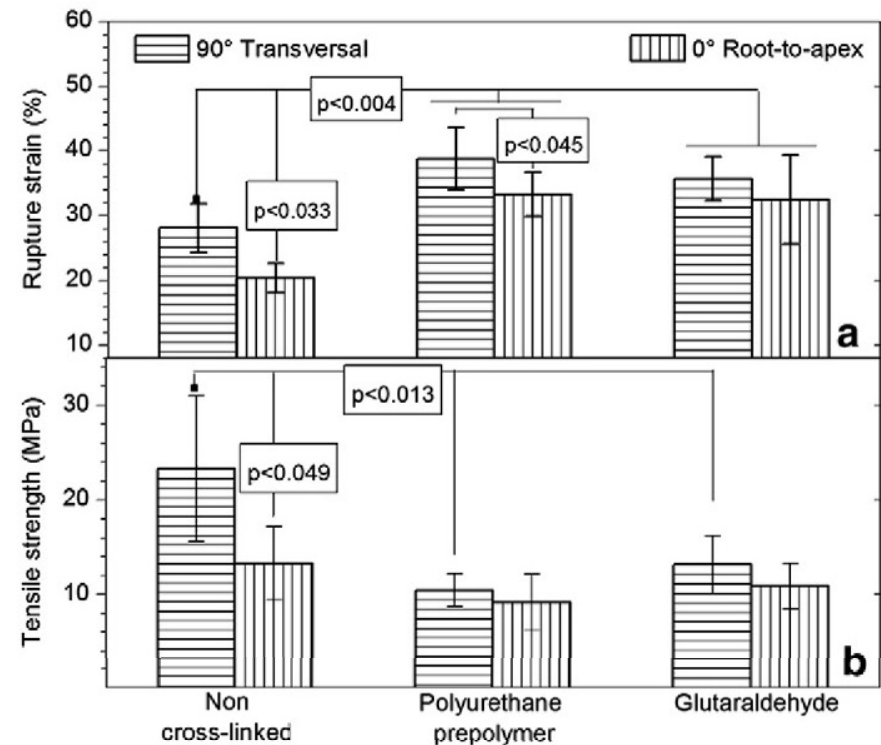

Fig. 8. Rupture properties for non-cross-linked and cross-linked matrix in both orthogonal directions. Data are expressed as mean values $\pm S D, n=6$.

environment (PBS immersion) at body temperature (Fig. 5). The alteration of stress relaxation behavior after cross-linking of the acellular material (Table 4) suggests that the effect of collagen inter-fibrillar cross-linking by GA over tensile viscoelastic properties is similar in PUP-cross-linked material. Perhaps, the pericardium viscous components are removed from the tissue during the PUP cross-linking [40]. The reduction of tensile modulus (Table 5) and mechanical anisotropy at rupture (Fig. 8) after PUP cross-linking are also indicative of the fixation of the collagen fibers, which are structured like laminar composite. In cross-linked pericardial tissue, the collagen fibers are poorly aligned in the direction of applied charge (Fig. 6). The increment of strain at rupture (Fig. 8 ) has been associated to tissue shrinkage during the cross-linking process [47].

The results of the present study indicate that the polymeric structure, flexibility and hydrophilicity of the PUP cross-linker do not affect the tensile mechanical properties of bovine pericardial tissue (Fig. 8) being as effective as the GA cross-linker. However, collagen fiber network was retained after PUP-cross-linking also providing resistance to enzymatic degradation. As a final comment we can say that the tissue stabilization with the novel method described in this study resulted in different extensions of cross-linking, preservation of the porous structure and rupture features but alteration of the viscoelastic behavior at similar levels to GA method. In agreement with the use of the pericardial matrix as tissue engineering scaffold, the cell-material interactions and the effect of PUP cross-linking extension over cell adhesion to material are being studied along with the effect of biodegradation products of PUP-stabilized collagen on cellular viability and they will be the subjects for another paper.

\section{Conclusions}

The treatment of a biological scaffold with PUP is an effective method for stabilizing collagen, while showing tensile properties comparable to the GA-treated one. The collagen network is coated with PUP which increases its resistance to collagenase digestion but retains porosity. The degree of the cross-linking with PUP is controlled by process parameters ( $\mathrm{pH}$, volume); exhibiting up to $81 \%$ of blocked amines and $12{ }^{\circ} \mathrm{C}$ of denaturation temperature higher than the acellular pericardial scaffold.

\section{Acknowledgments}

BMN thanks CONACYT (Mexico) for a PhD scholarship. We thank R. Vargas-Coronado for her technical assistance in the SEM analysis. The authors are also grateful for financial supports given by the Spanish Ministerio de Ciencia e Innovación and the Universidad de Guanajuato (Mexico) through the research projects MAT2009-10258 and UGTO0144/11, respectively.

\section{References}

[1] P.M. Crapo, T.W. Gilbert, S.F. Badylak, Biomaterials 32 (2011) 3233.

[2] P. Zilla, J. Brink, P. Human, D. Bezuidenhout, Biomaterials 29 (2008) 385.

[3] T.C. Flanagan, A. Pandit, Eur. Cell Mater. 6 (2003) 28.

[4] I. Vesely, Circ. Res. 97 (2005) 743.

[5] C.E. Schmidt, J.M. Baier, Biomaterials 21 (2000) 2215

[6] M.I. Matsagas, C. Bali, E. Arnaoutoglou, J.C. Papakostas, C. Nassis, G. Papadopoulos, A.M. Kappas, Ann. Vasc. Surg. 20 (2006) 614.

[7] J.N. Limpert, A.R. Desai, A.L. Kumpf, M.A. Fallucco, D.L. Aridge, Am. J. Surg. 198 (2009) e60.

[8] G. Lazarou, K. Powers, C. Pena, L. Bruck, M.S. Mikhail, Int. Urogynecol. J. 16 (2005) 242.

[9] D.J. Allen, L.J.A. Didio, Anat. Rec. 208 (1984) 7A.

[10] J.M. Lee, D.R. Boughner, Circ. Res. 49 (1981) 533

[11] A.W. Wiegner, O.H. Bing, T.K. Borg, J.B. Caulfield, Circ. Res. 49 (1981) 807

[12] J.M. Lee, D.R. Boughner, Circ. Res. 55 (1985) 475.

[13] P. Zioupos, J.C. Barbenel, Biomaterials 15 (1994) 366.

[14] E.C. Soller, D.S. Tzeranis, K. Miu, P.T.C. So, I.V. Yannas, Biomaterials 33 (2012) 4783

[15] J. Haag, S. Baiguera, P. Jungebluth, D. Barale, C. Del Gaudio, F. Castiglione, A. Bianco, C.E. Comin, D. Ribatti, P. Macchiarini, Biomaterials 33 (2012) 780.

[16] J.M. Connolly, I. Alferiev, J.N. Clark-Gruel, N. Eidelman, M. Sacks, E. Palmatory, A. Kronsteiner, S. DeFelice, J. Xu, R. Ohri, N. Narula, N. Vyavahare, R.J. Levy, Am. J. Pathol. 166 (2005) 1.

[17] F. Everaerts, M. Torrianni, M. van Luyn, P. van Wachem, J. Feijen, M. Hendricks, Biomaterials 24 (2004) 5523.

[18] P. Zilla, D. Bezuidenhout, P. Human, Ann. Thorac. Surg. 79 (2005) 905.

[19] T. Xi, J. Ma, W. Tian, X. Lei, S. Long, B. Xi, J. Biomed. Mater. Res. 26A (1992) 1241.

[20] B. Han, J. Jaurequi, W.B. Tang, M.E. Nimni, J. Biomed. Mater. Res. 65A (2003) 118.

[21] S. Jus, I. Stachel, W. Schloegl, M. Pretzler, W. Friess, M. Meyer, R. Birner-Gruenberger, G.M. Guebitz, Mater. Sci. Eng. C 31 (2011) 1068

[22] B.P. Chan, O.C.M. Chan, K.F. So, Acta Biomater. 4 (2008) 1627

[23] A. Oosthuysen, P.P. Zilla, P.A. Human, C.A.P. Schmidt, D. Bezuidenhout, Biomaterials 27 (2006) 2123.

[24] R. Tu, C.L. Lu, K. Thyagarajan, E. Wang, H. Nguyen, S. Shen, C. Hata, R.C. Quijano, J. Biomed. Mater. Res. 27 (1993) 3.

[25] G.N. Nogueira, A.C.D. Rodas, R.F. Weska, C.G. Aimoli, M. Maizato, A.A. Leiner, R.N.M. Pitombo, B. Polakiewicz, M.M. Beppu, Mater. Sci. Eng. C 30 (2010) 575.

[26] U.A. Stocka, K. Schenke-Layland, Biomaterials 27 (2006) 1.

[27] C. Yao, M. Markowicz, N. Pallua, E.M. Noah, G. Steffens, Biomaterials 29 (2008) 66.

[28] W.A. Naimark, C.A. Pereira, K. Tsang, J.M. Lee, J. Mater. Sci. Mater. Med. 6 (1995) 235.

[29] Q. Ye, M.C. Harmsen, M.J.A. van Luyn, R.A. Bank, Biomaterials 31 (2010) 9192.

[30] E. Jorge-Herrero, N. Olmo, J. Turnay, M. Martín-Maestro, S. Morales, J.M. García-Páez, M.A. Lizarbe, 19th Eur. Conf. on Biomaterials, Sorrento Italy, September, 2005.

[31] L.H.H. Olde Damink, P.J. Dijkstra, M.J.A. Luyn, P.B. Wachem, P. Nieuwenhuis, J. Feijen, J. Mater. Sci. Mater. Med. 6 (1995) 429

[32] W.K. Loke, E. Khor, A. Wee, S.H. Teoh, K.S. Chian, Biomaterials 17 (1996) 2163.

[33] S. Petersen, Ann. Chem. 562 (1949) 205.

[34] G.B. Guise, M.B. Jackson, J.A. MacLaren, Aust. J. Chem. 25 (1972) 2583.

[35] G.B. Guise, J. Appl. Polym. Sci. 21 (1977) 3427.

[36] J.L. Mata-Mata, D. Mendoza-Olivares, D.I. Alvarado-Castro, F.J. Amézquita-López, Polímeros 18 (2008) 138.

[37] J. Guan, M.S. Sacks, E.J. Beckman, W.R. Wagner, Biomaterials 25 (2004) 85.

[38] S.C. Vasudev, T. Chandy, J. Mater. Sci. Mater. Med. 10 (1999) 121.

[39] K.D. Park, W.K. Lee, J.Y. Yun, D.K. Han, S.H. Kim, Y.H. Kim, H.M. Kim, K.T. Kim, Biomaterials 18 (1997) 47.

[40] B. Mendoza-Novelo, E.E. Avila, J.V. Cauich-Rodríguez, E. Jorge-Herrero, F.J. Rojo, G.V. Guinea, J.L. Mata-Mata, Acta Biomater. 7 (2011) 1241.

[41] B. Mendoza-Novelo,J.V.Cauich-Rodríguez, J. Appl. Biomater. Biomech. 7 (2009) 123.

[42] ASTM Standard test method for shrinkage temperature of leather, (1997) D 6076-97, 637-639.

[43] G.V. Guinea, J.M. Atienza, P. Fantidis, F.J. Rojo, A. Ortega, M. Torres, P. Gonzalez, M.L. Elices, K. Hayashi, M. Elices, Ann. Biomed. Eng. 36 (2008) 66.

[44] A.C. Duncan, D. Boughner, Biomaterials 19 (1998) 777.

[45] E.Jorge-Herrero, C. Fonseca, A.P. Barge, J.Turnay, N. Olmo, P. Fernández, M.A. Lizarbe, J.M. García-Páez, Artif. Organs 34 (2010) E168.

[46] H.J. Wei, H.C. Liang, M.H. Lee, Y.C. Huang, Y. Chang, H.W. Sung, Biomaterials 26 (2005) 1905.

[47] J.M. Lee, S.A. Haberer, D.R. Boughner, J. Biomed. Mater. Res. 23 (1989) 457. 